\title{
Part 2. Biosafety
}

\section{COMPARATIVE ASSESSMENT OF THE EFFECT OF DISINFECTANTS ON THE LEVEL OF BIOTIC CONTAMINATION AND HATCHABILITY OF CHICKEN EGGS}

\author{
Stegniy B. T. ${ }^{1}$, Paliy A. P. ${ }^{1}$, Pavlichenko O. V. ${ }^{2}$, Stegniy O. O. ${ }^{3}$, Palii A. P. ${ }^{4}$ \\ ${ }^{1}$ National Scientific Center 'Institute of Experimental and Clinical \\ Veterinary Medicine', Kharkiv, Ukraine; e-mail: paliy.dok@gmail.com \\ ${ }^{2}$ Kharkiv State Zooveterinary Academy, Kharkiv, Ukraine \\ ${ }^{3}$ Odesa Research Station of the National Scientific Center 'Institute of \\ Experimental and Clinical Veterinary Medicine', Odesa, Ukraine \\ ${ }^{4}$ Kharkiv Petro Vasylenko National Technical \\ University of Agriculture, Kharkiv, Ukraine
}

\begin{abstract}
Summary. The widespread presence of modern high-productive egg crosses of chickens in poultry farms causes some negative consequences, one of which is a decrease in hatchability and survival of young chickens. The worsening of the quality of hatching eggs is associated with a violation of the morphological and biochemical parameters of the shell and shell membranes, which leads to the egg breakage, increased hatchery waste, contamination of young birds with infectious agents, and reduced immune resistance. Modern poultry farming uses a fairly large arsenal of disinfectants of various chemical origins and mechanisms of action. The introduction into practice of disinfectants is not possible without prior laboratory evaluation of their effectiveness as to the object of intended use. The aim of our work was to determine the bactericidal properties of disinfectants with different active substances in relation to the microbiota of hatching eggs from chickens of different productivity directions. The research was conducted following the guidelines 'Methods for determining and evaluating the safety and quality of disinfectants, detergents and detergent-sanitizers used in the production, storage, transportation and sale of animal products' (Kotsiumbas et al., 2010). According to the results of the research, it was found that for the purpose of pre-incubation treatment and during the incubation period for chickens it is effective to use the drug 'Polydez' in $0.1 \%$ concentration and the drug 'Virosan' in a concentration of $0.1 \%$. These disinfectants can be used for sanitation of chicken hatching eggs and hatcheries
\end{abstract}

Keywords: incubation, microorganisms, Polydez, Virosan, Sterylii AB, concentration

Introduction. Incubation of eggs is a complex process that requires special knowledge and equipment. The incubation conditions determine the process of embryonic development of birds. Even highly qualified specialists are sometimes unable to control this process, despite the fact that it is possible to control the development of the embryo and its membranes, to monitor the timeliness of changes in their size and position, and to predict qualitative and quantitative results of incubation long before its completion, and, if necessary, adjust the incubation conditions (Van de Ven et al., 2011; Damaziak et al., 2018).

Achievements of world science and advanced production can significantly increase the hatchability of eggs and the quality of day-old birds (Almeida et al., 2008). To obtain positive results it is necessary to meet a number of conditions, which include the presence of modern incubators, main and auxiliary facilities, biologically complete eggs, qualified personnel, strict adherence to the sequence of the technological process (Boleli et al., 2016; Palii et al., 2020; Nasri et al., 2020).
Today, it is important to develop measures to prevent the deterioration of the quality of hatching eggs and, as a consequence, reduce their hatchability, which is inherent in modern poultry egg crosses (Kutsira, Nwulu and Dogo, 2019). Deterioration of quality indicators is associated primarily with a violation of the parameters of the protective bioceramic structures of eggs, which include shells and shell membranes (Svobodová and Tůmová, 2015; Hincke et al., 2019). Violation of the structural formations of the hatching eggs leads to a noticeable egg breakage, contamination by pathogenic microflora of young birds and a decrease in their immune resistance (Cook et al., 2005a). A necessary condition for the production of high quality and safe poultry products is effective sanitation of eggs (Sander and Wilson, 1999).

Microbial contamination of incubating and hatching cabinets depends on the degree of microbial contamination of eggs entering the incubator (Cook et al., 2005b). Increased content of pathogenic microflora on the surface of the shell, in the air pool of the incubator, on the surface of its equipment and ventilation ducts leads to a 
decrease in hatchability of eggs (Furuta and Maruyama, 1981; Grizard et al., 2014).

There is also a mass infection of embryos, and subsequently a significant lag in the growth and development of hatched young, reducing its resistance and safety during growing (Wang, Firestone and Beissinger, 2011). The level of contamination of the egg surface depends on the degree of microbial contamination of containers, equipment, indoor air (poultry house, egg storage, hatchery, etc.) (Grizard et al., 2014).

Pathogenic microorganisms spread among susceptible poultry in case of non-compliance with veterinary and sanitary norms and rules (Zavgorodniy et al., 2013; Paliy and Paliy, 2019), which in turn requires a scientifically sound application of highly effective disinfectants with a wide range of biocidal action (Paliy et al., 2015; Paliy, 2018; Stegniy et al., 2019; Kovalenko et al., 2020).

In connection with the above, the task of veterinary science includes the development and production testing of new detergents and disinfectants (Paliy et al., 2016; Bondarchuk, Paliy and Blazheyevskiy, 2019), as well as egg processing technologies from the moment of laying eggs to the hatching of young poultry (Samiullah et al., 2013). It is necessary to keep in mind not only the filling of the shortage of drugs, but also to take into account the increasing requirements for labor safety and the environment protection from pollution (Buhr et al., 2015; Jiang et al., 2018; Paliy et al., 2020d).

Currently, the main method of disinfection is chemical. It is based on the application of disinfectants from different chemical groups, which must meet a number of modern requirements (Paliy et al., 2020c). Treatment of hatching eggs by chemical methods involves the use of substances having bactericidal, bacteriostatic and fungicidal activity (Kalidari et al., 2009; Olsen et al., 2017). Measures to control and prevent diseases of poultry of various etiologies should be based on a comprehensive approach to the technological process of decontamination of both environmental objects and eggs from the moment of their laying to hatching (Kusstatscher et al., 2017; Paliy et al., 2018a).

Existing egg disinfectants used before placing eggs in the incubator and during the incubation period need to be revised to take into account new approaches to assessing their effectiveness.

The aim of the study was to determine the bactericidal properties of disinfectants with different active substances in relation to the microbiota of hatching eggs from chickens of different productivity directions.

Materials and methods. For research we have chosen disinfectants with various active substances:

'Polydez' - a disinfectant that contains hydrogen peroxide $(12.5 \pm 2.5 \%)$ and benzalkonium chloride (QACs) $(15 \pm 1 \%)$ as the active substance. In addition, the composition includes cocamidopropyl betaine, neonol and other components.
'Sterylii $\mathrm{AB}$ ' - a disinfectant containing: derivatives of salts of guanidine and alkylamine; sodium bicarbonate; excipients; drinking water - up to $100 \%$.

'Virosan' - a disinfectant containing benzalkonium chloride (QACs) - 25.0\%, glutar aldehyde - $11.0 \%$, excipients.

Study of bactericidal properties of disinfectants was carried out following the guidelines 'Methods for determining and evaluating safety and quality of disinfectants, detergents-disinfectants used in the production, storage, transportation and sale of animal products' (Kotsiumbas et al., 2010) and other current methods (Kovalenko et al., 2014).

Eggs from layers and broilers were used for incubation.

Results and discussions. At the first stage of research we determined the possibility of incubation of eggs from chickens of different directions of productivity in case of treatment with various disinfectants. The results of bacteriological studies of washes showed that in the case of incubation of eggs of different groups in one cabinet, regardless of the drug used, the level of microbiological contamination of the egg shell surface during incubation of eggs is almost equally stable (Table 1). The results presented in Table 1 indicate that in one incubating cabinet the level of microbiological contamination of the egg surface does not depend on the use of disinfectants with different active substances, as the microbial background is aligned with the circulating air.

In the next experiment, mycological studies showed that on the $7^{\text {th }}$ day of incubation, the number of micromycete spores on the surface of the egg shell in the group in which the drug 'Polydez' was used, was $0.200 \times 10^{4}$, and in the group where the drug 'Virosan' was used - the growth of microscopic fungi was not found (Table 2). On the $12^{\text {th }}$ day of incubation, almost the same level of contamination of eggs with micromycetes was observed: $\quad(0.875 \pm 0.012) \times 10^{4}-\quad$ 'Polydez' and $(0.075 \pm 0.001) \times 10^{4}-$ 'Virosan'. Additional treatment of eggs on the $14^{\text {th }}$ day of incubation significantly reduced the mycological load $-(0.075 \pm 0.002) \times 10^{4}$ ('Polydez') and $(0.050 \pm 0.006) \times 10^{4}$ ('Virosan') spores on the surface of the shell of 18-day-old embryos. In the groups without additional treatment with disinfectants, the number of microscopic fungi was almost twice higher $(0.125 \pm 0.003) \times 10^{4}$ ('Polydez') and $(0.150 \pm 0.002) \times 10^{4}$ ('Virosan') spores on the egg surface.

A comparative analysis of the effect of disinfectants 'Polydez' and 'Virosan' on the bacterial contamination of the surface of the egg shell is presented in Table 3. The level of contamination of the egg shell surface with microorganisms before incubation was $>10^{4}$ (Escherichia coli, Corynebacterium spp., Staphylococcus spp., Streptococcus spp.). After disinfection with drugs and placing eggs for incubation, the total bacterial contamination significantly decreased $\left(7^{\text {th }}\right.$ day of incubation - $1.0 \pm 0.1 \mathrm{CFU}$ by 'Polydez' and 
$2.0 \pm 0.1$ CFU by'Virosan'). On the $12^{\text {th }}$ day of incubation, the total bacterial contamination had already increased several times and amounted to $10.0 \pm 0.5$ CFU by 'Polydez' and $30.0 \pm 0.4 \mathrm{CFU}$ by 'Virosan'. Additional treatment of eggs on the $14^{\text {th }}$ day of incubation significantly reduced the microbiological load in both groups ( 10 times by 'Polydez' and 30 times by 'Virosan'). The surface of the egg shell without additional treatment on the $14^{\text {th }}$ day of incubation remained at the level of 12-day-old embryos $(10.0 \pm 0.2 \mathrm{CFU}$ by 'Polydez' and $30.0 \pm 0.3 \mathrm{CFU}$ by 'Virosan').

The results of tests of the effect of disinfectants 'Polydez' and 'Virosan' on the hatchability of eggs are given in Table 4.

Table 1 - The results of bacteriological studies of washes from the surface of the shell of eggs that were incubated in one cabinet

\begin{tabular}{|c|c|c|}
\hline \multirow{2}{*}{ Day of incubation } & Eggs from layers $(n=120)$ & Broiler eggs $(n=100)$ \\
\hline & 'Polydez', 0.1\% & 'Sterylii AB', 1.0\% \\
\hline Before incubation & \multicolumn{2}{|c|}{$>10^{4}$ Escherichia coli, Corynebacterium spp., Staphylococcus spp., Streptococcus spp. } \\
\hline $7^{\text {th }}$ day & $>10^{4}$ Escherichia coli, Staphylococcus spp. & $\begin{array}{l}>10^{4} \text { Escherichia coli, Corynebacterium spp., } \\
\text { Staphylococcus spp., fungal microflora }\end{array}$ \\
\hline $11^{\text {th }}$ day & \multicolumn{2}{|c|}{$>10^{4}$ Staphylococcus spp., fungal microflora } \\
\hline $17^{\text {th }}$ day & \multicolumn{2}{|c|}{$>10^{4}$ Escherichia coli, fungal microflora } \\
\hline
\end{tabular}

Table 2 - The results of mycological studies of washes from the surface of the shell of eggs treated with disinfectants

\begin{tabular}{|c|c|c|c|}
\hline Drug & Day of incubation & \multicolumn{2}{|c|}{ The level of contamination by micromycetes } \\
\hline \multirow{4}{*}{$\begin{array}{l}\text { 'Polydez', } \\
0.1 \%\end{array}$} & $7^{\text {th }}$ day & \multicolumn{2}{|c|}{$(0.200 \pm 0.005) \times 10^{4}$ spores on the egg surface $\left(\mathrm{S}_{\text {average }}=65.0 \pm 2.0 \mathrm{sm}^{2}\right)$} \\
\hline & $12^{\text {th }}$ day & \multicolumn{2}{|c|}{$(0.875 \pm 0.012) \times 10^{4 *}$ spores on the egg surface $\left(\mathrm{S}_{\text {average }}=62.0 \pm 2.0 \mathrm{sm}^{2}\right)$} \\
\hline & $14^{\text {th }}$ day & Additional treatment of eggs & Without additional treatment \\
\hline & $18^{\text {th }}$ day & $\begin{array}{c}(0.075 \pm 0.002) \times 10^{4} \text { spores on the egg } \\
\text { surface }\left(\mathrm{S}_{\text {average }}=64.0 \pm 2.0 \mathrm{sm}^{2}\right)\end{array}$ & $\begin{array}{c}(0.125 \pm 0.003) \times 10^{4} \text { spores on the egg } \\
\text { surface }\left(\mathrm{S}_{\text {average }}=60.0 \pm 2.0 \mathrm{sm}^{2}\right)\end{array}$ \\
\hline \multirow{4}{*}{$\begin{array}{l}\text { 'Virosan', } \\
0.1 \%\end{array}$} & $7^{\text {th }}$ day & \multicolumn{2}{|c|}{ growth of microscopic fungi has not been established $\left(\mathrm{S}_{\text {average }}=65.0 \pm 2.0 \mathrm{sm}^{2}\right)$} \\
\hline & $12^{\text {th }}$ day & \multicolumn{2}{|c|}{$(0.075 \pm 0.001) \times 10^{4 \star}$ spores on the egg surface $\left(\mathrm{S}_{\text {average }}=68.0 \pm 2.0 \mathrm{sm}^{2}\right)$} \\
\hline & $14^{\text {th }}$ day & Additional treatment of eggs & Without additional treatment \\
\hline & $18^{\text {th }}$ day & $\begin{array}{c}(0.050 \pm 0.006) \times 10^{4} \text { spores on the egg } \\
\text { surface }\left(\mathrm{S}_{\text {average }}=66.0 \pm 2.0 \mathrm{~cm}^{2}\right)\end{array}$ & $\begin{array}{c}(0.150 \pm 0.002) \times 10^{4} \text { spores on the egg } \\
\text { surface }\left(\mathrm{S}_{\text {average }}=70.0 \pm 2.0 \mathrm{sm}^{2}\right)\end{array}$ \\
\hline
\end{tabular}

Note. ${ }^{\star}-\mathrm{p}<0.05$ in relation to the $7^{\text {th }}$ day of incubation.

Table 3 - The effect of disinfectants 'Polydez' and 'Virosan' on bacterial contamination of the egg shell surface $(\mathrm{n}=3)$

\begin{tabular}{|c|c|c|c|c|}
\hline Day of incubation & \multicolumn{2}{|c|}{ 'Polydez', $0.1 \%$} & \multicolumn{2}{|c|}{ 'Virosan', $0.1 \%$} \\
\hline Before incubation & \multicolumn{4}{|c|}{$>10^{4}$ Escherichia coli, Corynebacterium spp., Staphylococcus spp., Streptococcus spp. } \\
\hline $7^{\text {th }}$ day & \multicolumn{2}{|c|}{$1.0 \pm 0.1 \mathrm{CFU}$} & \multicolumn{2}{|c|}{$2.0 \pm 0.1 \mathrm{CFU}$} \\
\hline $12^{\text {th }}$ day & \multicolumn{2}{|c|}{$10.0 \pm 0.5 \mathrm{CFU}^{*}$} & \multicolumn{2}{|c|}{$30,0 \pm 0,4 \mathrm{CFU}{ }^{\star}$ Acinetobacter spp. } \\
\hline $14^{\text {th }}$ day & $\begin{array}{c}\text { Additional treatment } \\
\text { of eggs }\end{array}$ & $\begin{array}{c}\text { Without additional } \\
\text { treatment }\end{array}$ & $\begin{array}{c}\text { Additional treatment } \\
\text { of eggs }\end{array}$ & $\begin{array}{c}\text { Without additional } \\
\text { treatment }\end{array}$ \\
\hline $18^{\text {th }}$ day & $1.0 \pm 0.2 \mathrm{CFU}$ & $10.0 \pm 0.2 \mathrm{CFU}$ & $1.0 \pm 0.1 \mathrm{CFU}$ & $30.0 \pm 0.3 \mathrm{CFU}$ \\
\hline
\end{tabular}

Notes: CFU - colony-forming units; ${ }^{*}-\mathrm{p}<0.05$ in relation to the $7^{\text {th }}$ day of incubation.

Table 4 - Hatchability of eggs treated with various disinfectants

\begin{tabular}{|c|c|c|c|c|c|c|c|c|c|c|c|c|c|}
\hline \multirow{2}{*}{$\begin{array}{c}\text { Placed } \\
\text { eggs, } \\
\text { pcs. }\end{array}$} & \multicolumn{2}{|c|}{$\begin{array}{c}\text { Not } \\
\text { fertilized }\end{array}$} & \multicolumn{2}{|c|}{ Blood ring } & \multicolumn{2}{|c|}{ Dead-in-shell } & \multicolumn{2}{|c|}{ Addled eggs } & \multicolumn{2}{|c|}{$\begin{array}{l}\text { Weak and } \\
\text { crippled }\end{array}$} & \multicolumn{2}{|c|}{$\begin{array}{l}\text { Hatched } \\
\text { chickens }\end{array}$} & \multirow{2}{*}{$\begin{array}{c}\begin{array}{c}\text { Hatch- } \\
\text { ability }\end{array} \\
\%\end{array}$} \\
\hline & pcs. & $\%$ & pcs. & $\%$ & pcs. & $\%$ & pcs. & $\%$ & pcs. & $\%$ & heads & $\%$ & \\
\hline \multicolumn{14}{|c|}{ 'Polydez' } \\
\hline 61 & 14 & 23.0 & 6 & 9.8 & 2 & 3.3 & 2 & 3.3 & - & - & 37 & 60.7 & 78.7 \\
\hline \multicolumn{14}{|c|}{ 'Virosan' } \\
\hline 61 & 14 & 23.0 & 9 & 14.8 & 4 & 6.6 & 2 & 3.3 & - & - & 32 & 52.5 & 68.0 \\
\hline \multicolumn{14}{|c|}{ Total } \\
\hline 122 & 28 & 23.0 & 15 & 12.3 & 6 & 4.9 & 4 & 3.3 & - & - & 69 & 56.6 & 70.2 \\
\hline
\end{tabular}


From the results shown in Table 4 it is seen that the hatchability of eggs in the group, the surface of the shell of which before incubation was treated with $0.1 \%$ solution of the drug 'Polydez' was 78.7\%, and in the group where the surface of the shell before incubation was treated with $0.1 \%$ solution of the drug 'Virosan' was $68.0 \%$. The main losses during the incubation period were due to the presence of an increased number of unfertilized eggs (23.0\%).

Autopsy of the dead embryos did not show a negative effect of disinfectants on the hatching egg quality. It should be noted that in the group of eggs, the surface of the shell of which before incubation was treated with $0.1 \%$ solution of the drug 'Virosan', there was a slightly increased rate of embryo death in the middle of incubation (blood ring, dead-in shell) compared to the group where the surface of the shell before incubation was treated with $0.1 \%$ solution of the drug 'Polydez'. However, in our opinion, this is more due to the excessive period (about 10 days for collecting eggs to form a batch) of egg storage before incubation.

Summarizing the results of the study, it was found that the drugs 'Polydez, 'Virosan', and 'Sterylii AB' do not have a negative impact on the development of birds in the embryonic and postnatal periods. However, due to the lack of fungicidal properties, 'Sterylii AB' should not be used to disinfect egg surfaces before incubation. For the purpose of both pre-incubation treatment and during the incubation period, it is recommended to use for chicken eggs the drug 'Polydez' in $0.1 \%$ concentration and the drug 'Virosan' in a concentration of $0.1 \%$.

The large-scale application of disinfectants in animal husbandry is caused by the widespread of pathogens of animal diseases regardless of the facility and areas (Paliy et al., 2018c, 2019). The intensification of production has led to the concentration of a large number of birds of different ages in relatively limited areas. Violation of basic zooveterinary requirements in egg and meat production very often leads to diseases of various etiologies in poultry (Paliy et al., 2018b; Bogach et al., 2020; Paliy et al., 2020a). This is due to the fact that the air basin at such poultry farms is heavily polluted by microflora due to violations in various technological operations for clean and dirty air flows (Palii et al., 2019).

The possibility of re-infection of poultry increases due to the lack of cleaning of the supply and exhaust air in the adjacent premises, as well as due to the placing of eggs for incubation from both healthy and sick birds. In this regard, almost every world leader in incubator construction has its own technological approach to the treatment of premises, equipment, hatching eggs, disinfection and supply of air to the incubator, the scheme of its distribution and the level of air exchange in rooms, cabinets, etc. (Jiang et al., 2018).

One of the key stages of egg incubation is the genetic potential and age of the parent flock (Nangsuay et al., 2013; Ipek and Sozcu, 2015), the shelf life of eggs before incubation (Fasenko, 2007; Goliomytis, Tsipouzian and Hager-Theodorides, 2015), egg size (Iqbal et al., 2016), timely and careful overturning (Elibol and Braket, 2003), quality of ventilation (Okur, Eleroğlu and Türkoğlu, 2018; Ishchenko et al., 2019). For sanitary treatment of eggs before incubation it is necessary to use only those antimicrobials, the effectiveness of which is proven in the laboratory, and their properties meet modern requirements for high quality and safe production (Gehan et al., 2009; Banach et al., 2016; Paliy et al., 2020b; Orobchenko et al., 2020).

In this regard, the urgent issue today is to determine the effect of new disinfectants on the egg microbiota, embryogenesis of poultry, growth and development of hatched young birds, the level of their resistance and safety during growing.

Conclusions. In the course of research the bactericidal properties of disinfectants with different active substances on the microbiota of hatching eggs from chickens of different directions of productivity were determined.

For the purpose of pre-incubation and during the incubation period treatment of chicken eggs, it is effective to use the drug 'Polydez' in $0.1 \%$ concentration and the drug 'Virosan' in a concentration of $0.1 \%$.

These disinfectants can be used for sanitation of chicken hatching eggs.

\section{References}

Almeida, J. G., Vieira, S. L., Reis, R. N., Berres, J., Barros, R., Ferreira, A. K. and Furtado, F. V. F. (2008) 'Hatching distribution and embryo mortality of eggs laid by broiler breeders of different ages', Brazilian Journal of Poultry Science [Revista Brasileira de Ciência Avícola], 10(2), pp. 89-96. doi: 10.1590/S1516-635X2008000200003.

Banach, M., Tymczyna, L., Chmielowiec-Korzeniowska, A. and Pulit-Prociak, J. (2016) 'Nanosilver biocidal properties and their application in disinfection of hatchers in poultry processing plants', Bioinorganic Chemistry and Applications, 2016, p. 5214783. doi: 10.1155/2016/5214783.

Bogach, M. V., Paliy, A. P., Perots'ka, L. V., Pyvovarova, I. V., Stoyanova, V. Y. and Palii, A. P. (2020) 'The influence of hydro- meteorological conditions on the spread of chicken Cestodiasis', Regulatory Mechanisms in Biosystems, 11(3), pp. 414-418. doi: 10.15421/022063.

Boleli, I. C., Morita, V. S., Matos Jr, J. B., Thimotheo, M. and Almeida, V. R. (2016) 'Poultry egg incubation: Integrating and optimizing production efficiency', Brazilian Journal of Poultry Science [Revista Brasileira de Ciência Avícola], 18(spe2), pp. 1-16. doi: 10.1590/1806-9061-2016-0292.

Bondarchuk, A. O., Paliy, A. P. and Blazheyevskiy, M. Ye. (2019) 'Determination of acute toxicity of the "Bondarmin" disinfectant', Journal for Veterinary Medicine, Biotechnology and Biosafety, 5(2), pp. 26-30. doi: 10.36016/JVMBBS-2019-5-2-5. 
Buhr, R. J., Mauldin, J. M., Bailey, J. S. and Cox, N. A. (1994) 'Automated spray sanitizing of broiler hatching eggs 2. Hatchability of nest clean and dirty eggs', Journal of Applied Poultry Research, 3(3), pp. 226-233. doi: 10.1093/japr/3.3.226.

Cook, M. I., Beissinger, S. R., Toranzos, G. A. and Arendt, W. J. (2005a) 'Incubation reduces microbial growth on eggshells and the opportunity for trans-shell infection: Incubation reduces microbes on eggshells, Ecology Letters, 8(5), pp. 532-537. doi: 10.1111/j.1461-0248.2005.00748.x.

Cook, M. I., Beissinger, S. R., Toranzos, G. A., Rodriguez, R. A. and Arendt, W. J. (2005b) 'Microbial infection affects egg viability and incubation behavior in a tropical passerine', Behavioral Ecology, 16(1), pp. 30-36. doi: 10.1093/beheco/ $\operatorname{arh131.~}$

Damaziak, K., Pawęska, M., Gozdowski, D. and Niemiec, J. (2018) 'Short periods of incubation, egg turning during storage and broiler breeder hens age for early development of embryos, hatching results, chicks quality and juvenile growth', Poultry Science, 97(9), pp. 3264-3276. doi: 10.3382/ps/pey163.

Elibol, O. and Braket, J. (2003) 'Effect of frequency of turning from three to eleven days of incubation on hatchability of broiler hatching eggs', Poultry Science, 82(3), pp. 357-359. doi: 10.1093/ps/82.3.357.

Fasenko, G. M. (2007) 'Egg storage and the embryo', Poultry Science, 86(5), pp. 1020-1024. doi: 10.1093/ps/86.5.1020.

Furuta, K. and Maruyama, S. (1981) 'Bacterial contamination on eggs during incubation and hatching, and of fluffs of newlyhatched chicks', British Poultry Science, 22(3), pp. 247-254. doi: 10.1080/00071688108447883.

Gehan, M. Z., Anwer, W., Amer, H. M., El-Sabagh, I. M., Rezk, A. and Badawy, E. M. (2009) 'In vitro efficacy comparisons of disinfectants used in the commercial poultry farms', International Journal of Poultry Science, 8(3), pp. 237-241. doi: 10.3923/ijps.2009.237.241.

Goliomytis, M., Tsipouzian, T. and Hager-Theodorides, A. L. (2015) 'Effects of egg storage on hatchability, chick quality, performance and immunocompetence parameters of broiler chickens', Poultry Science, 94(9), pp. 2257-2265. doi: 10.3382/ps/ pev200.

Grizard, S., Dini-Andreote, F., Tieleman, B. I. and Salles, J. F. (2014) 'Dynamics of bacterial and fungal communities associated with eggshells during incubation', Ecology and Evolution, 4(7), pp. 1140-1157. doi: 10.1002/ece3.1011.

Hincke, M. T., Da Silva, M., Guyot, N., Gautron, J., McKee, M. D., Guabiraba-Brito, R. and Réhault-Godbert, S. (2019) 'Dynamics of structural barriers and innate immune components during incubation of the avian egg: Critical interplay between autonomous embryonic development and maternal anticipation', Journal of Innate Immunity, 11(2), pp. 111-124. doi: 10.1159/000493719.

Ipek, A. and Sozcu, A. (2015) 'The effects of broiler breeder age on intestinal development during hatch window, chick quality and first week broiler performance', Journal of Applied Animal Research, 43(4), pp. 402-408. doi: 10.1080/09712119. 2014.978783.

Iqbal, J., Khan, S. H., Mukhtar, N., Ahmed, T. and Pasha, R. A. (2016) 'Effects of egg size (weight) and age on hatching performance and chick quality of broiler breeder', Journal of Applied Animal Research, 44(1), pp.54-64. doi: 10.1080/09712119.2014.987294.
Ishchenko, K. V., $\quad$ Palii, A. P., $\quad$ Kis, V. M., $\quad$ Petrov, R. V., Nagorna, L. V., Dolbanosova, R. V. and Paliy, A. P. (2019) 'Investigation of microclimate parameters for the content of toxic gases in poultry houses during air treatment in the scrubber with the use of various fillers', Ukrainian Journal of Ecology, 9(2), pp. 74-80. Available at: https://www.ujecology. $\mathrm{com} /$ abstract/investigation-of-microclimate-parameters-for-th e-content-of-toxic-gases-in-poultry-houses-during-air-treatme nt-in-the-sc-25910.html.

Jiang, L., Li, M., Tang, J., Zhao, X., Zhang, J., Zhu, H., Yu, X., Li, Y., Feng, T. and Zhang, X. (2018) 'Effect of different disinfectants on bacterial aerosol diversity in poultry houses', Frontiers in Microbiology, 9, p. 2113. doi: 10.3389/fmicb.2018. 02113.

Kalidari, G. A., $\quad$ Moayyedian, H., $\quad$ Eslamian, A. and Mohsenzadeh, M. (2009) 'Isolation and identification of noncoliform Gram-negative bacteria in hatching eggs to evaluate the effect of egg fumigation by formaldehyde, The Journal of Poultry Science, 46(1), pp. 59-62. doi: 10.2141/jpsa.46.59.

Kotsiumbas, I. Ya., Serhiienko, O. I., Kovalchyk, L. M. et al. (2010) 'Methods for determining and evaluating the safety and quality of disinfectants, detergents and detergent-sanitizers used in the production, storage, transportation and sale of animal products: Guidelines' [Metody vyznachennia ta otsinky pokaznykiv bezpeky i yakosti dezinfikuiuchykh, myinodezinfikuiuchykh zasobiv, shcho zastosovuiutsia pid chas vyrobnytstva, zberihannia, transportuvannia ta realizatsii produktsii tvarynnoho pokhodzhennia: metodychni rekomendatsii], in Yakuchak, O. M. (ed.) Veterinary Disinfection, Deodorization, Disinsection, Disinvasion, Deratization: Instructions and Guidelines [Veterynarna dezinfektsiia, dezodoratsiia, dezinsektsiia, dezinvaziia, deratyzatsiia: instruktsiia ta metodychni rekomendatsii]. Kyiv: Bioprom, pp. 65-152. ISBN 9789662448047. [in Ukrainian].

Kovalenko, V. L. (ed.) (2014) Methods for Control of Disinfectants: A Handbook [Metody kontroliu dezinfikuiuchykh zasobiv: dovidnyk]. Kyiv: VSP 'IPO KNUBA' [in Ukrainian].

Kovalenko, V. L., $\quad$ Ponomarenko, G. V., Kukhtyn, M. D., Paliy, A. P., $\quad$ Bodnar, O. O., $\quad$ Rebenko, H. I., ～Kozytska, T. G., Makarevich, T. V., Ponomarenko, O. V. and Palii, A. P. (2020) 'Evaluation of acute toxicity of the "Orgasept" disinfectant', Ukrainian Journal of Ecology, 10(4), pp. 273-278. doi: 10.15421/ 2020_1982.

Kusstatscher, P., Cernava, T., Liebminger, S. and Berg, G. (2017) 'Replacing conventional decontamination of hatching eggs with a natural defense strategy based on antimicrobial, volatile pyrazines', Scientific Reports, 7(1), p. 13253. doi: 10.1038/ s41598-017-13579-7.

Kutsira, G. V., Nwulu, N. I. and Dogo, E. M. (2019) 'Development of a small scaled microcontroller-based poultry egg incubation system', 2019 International Artificial Intelligence and Data Processing Symposium (IDAP), Malatya, Turkey, 2122 September 2019. Malatya, Turkey: IEEE, pp. 1-7. doi: 10.1109/IDAP.2019.8875897.

Nangsuay, A., Meijerhof, R., Ruangpanit, Y., Kemp, B. and Van den Brand, H. (2013) 'Energy utilization and heat production of embryos from eggs originating from young and old broiler breeder flocks', Poultry Science, 92(2), pp. 474-482. doi: 10.3382/ps.2012-02643.

Nasri, H., Van den Brand, H., Najjar, T. and Bouzouaia, M. (2020) 'Egg storage and breeder age impact on egg quality and 
embryo development', Journal of Animal Physiology and Animal Nutrition, 104(1), pp. 257-268. doi: 10.1111/jpn.13240.

Okur, N., Eleroğlu, H. and Türkoğlu, M. (2018) 'Impacts of breeder age, storage time and setter ventilation program on incubation and post-hatch performance of broilers', Brazilian Journal of Poultry Science [Revista Brasileira de Ciência Avícola], 20(1), pp. 27-36. doi: 10.1590/1806-9061-2017-0550.

Olsen, R., Kudirkiene, E., Thøfner, I., Pors, S., KarlskovMortensen, P., Li, L., Papasolomontos, S., Angastiniotou, C. and Christensen, J. (2017) 'Impact of egg disinfection of hatching eggs on the eggshell microbiome and bacterial load', Poultry Science, 96(11), pp. 3901-3911. doi: 10.3382/ps/pex182.

Orobchenko, O. L., Roman'ko, M. Ye., Paliy, A. P., Dotsenko, R. V., Morozenko, D. V., Gliebova, K. V., Doletskyi, S. P. and Palii, A. P. (2020) 'Evaluation of $\mathrm{Ag}, \mathrm{Cu}, \mathrm{Fe}$ and $\mathrm{MnO}_{2}$ nanoparticle mixture effecton histomorphological state of internal organs and tissues in laying hens', Ukrainian Journal of Ecology, 10(4), pp. 165-174. doi: 10.15421/2020_184.

Palii, A. P., Pylypenko, S. H., Lukyanov, I. M., Zub, O. V., Dombrovska, A. V., Zagumenna, K. V., Kovalchuk, Y.O., Ihnatieva, T. M., Ishchenko, K. V., Paliy, A. P. and Orobchenko, O. L. (2019) 'Research of techniques of microclimate improvement in poultry houses', Ukrainian Journal of Ecology, 9(3), pp. 41-51. doi: 10.15421/2019_707.

Palii, A. P., Nanka, O. V., Kovalchuk, Y. O., Kovalchuk, A. O., Kalabska, V. S., Kholod, I. V., Pobirchenko, O. M., Umrihina, O. S., Poliakov, A. M., Ishchenko, K. V. and Paliy, A. P. (2020) 'Effect on the bactericidal device for decontamination the air microorganisms in poultry house on the content of toxic gases', Ukrainian Journal of Ecology, 10(1), pp. 24-29. doi: 10.15421/ 2020_4.

Paliy, A. P. (2018) 'Antibacterial effect of "Ecocide C" disinfectant against mycobacteria' [Efektyvnist antybakterialnoi dii dezinfikuiuchoho zasobu «Ekotsyd C» shchodo mikobakterii], Ukrainian Journal of Ecology, 8(1), pp. 141-147. doi: 10.15421/2018_198. [in Ukrainian].

Paliy, A. P. and Paliy, A. P. (2019) Technic and Technological Innovations in Dairy Cattle [Tekhniko-tekhnolohichni innovatsii $u$ molochnomu skotarstvi]. Kharkiv: Miskdruk. ISBN 9786176192077. [in Ukrainian].

Paliy, A. P., Zavgorodniy, A. I., Stegniy, B. T. and Gerilovych, A. P. (2015) 'A study of the efficiency of modern domestic disinfectants in the system of TB control activities', Agricultural Science and Practice, 2(2), pp.26-31. doi: 10.15407/agrisp2.02.026.

Paliy, A. P., Stegniy, B. T., Muzyka, D. V., Gerilovych, A. P. and Korneykov, O. M. (2016) 'The study of the properties of the novel virucidal disinfectant', Agricultural Science and Practice, 3(3), pp. 41-47. doi: 10.15407/agrisp3.03.041.

Paliy, A. P., Ishchenko, K. V., Marchenko, M. V., Paliy, A. P. and Dubin, R. A. (2018a) 'Effectiveness of aldehyde disinfectant against the causative agents of Tuberculosis in domestic animals and birds', Ukrainian Journal of Ecology, 8(1), pp. 845-850. doi: 10.15421/2018_283.

Paliy, A. P., Mashkey, A. M., Sumakova, N. V. and Paliy, A. P. (2018b) 'Distribution of poultry ectoparasites in industrial farms, farms, and private plots with different rearing technologies', Biosystems Diversity, 26(2), pp. 153-159. doi: 10.15421/011824.

Paliy, A. P., Sumakova, N. V., Mashkey, A. M., Petrov, R. V., Paliy, A. P. and Ishchenko, K. V. (2018c) 'Contamination of animal-keeping premises with eggs of parasitic worms', Biosystems Diversity, 26(4), pp. 327-333. doi: 10.15421/011848.

Paliy, A., Sumakova, N., Petrov, R., Shkromada, O., Ulko, L. and Palii, A. (2019) 'Contamination of urbanized territories with eggs of helmiths of animals', Biosystems Diversity, 27(2), pp. 118124. doi: 10.15421/011916.

Paliy, A. P., Sumakova, N. V., Petrov, R. V., Berezovskiy, A. V., Risovaniy, V. I., Z Zon, G. A., Ivanovskaya, L. B., Fotin, A. I., Dolbanosova, R. V., Livoshchenko, L. P., Livoshchenko, Ye. M. and Palii, A. P. (2020a) 'Endoparasic diseases of ostriches in eastern Ukraine', Ukrainian Journal of Ecology, 10(4), pp. 235241. doi: 10.15421/2020_193.

Paliy, A. P., Sumakova, N. V., Rodionova, K. O., Nalivayko, L. I., Boyko, V. S., Ihnatieva, T. M., Zhigalova, O. Ye., Dudus, T. V., Anforova, M. V., and Kazakov, M. V. (2020b) 'Disinvasive action of aldehyde and chlorine disinfectants on the test-culture of Toxocara canis eggs', Ukrainian Journal of Ecology, 10(4), pp. 175-183. doi: 10.15421/2020_185.

Paliy, A. P., Zavgorodnii, A. I., Kalashnyk, M. V., Shkromada, O. I., Rybachuk, Z. V., $\quad$ Dolbanosova, R. V., $\quad$ Kovalenko, L. M., Livoshchenko, Ye. M., Livoshchenko, L. P., Baidevliatova, Yu. V., Dunaiev, Yu. K., Palii, A. P. and Nedzheria, T. I. (2020c) 'Influence of new frost-resistant disinfectant on the ultrastructural organization of atypical mycobacteria', Ukrainian Journal of Ecology, 10(3), pp. 95-101. doi: 10.15421/2020_139.

Paliy, A. P., Zavgorodniy, A. I., Stegniy, B. T. and Palii, A. P. (2020d). Scientific and Methodological Grounds for Controlling the Development and Use of Disinfectants [Naukovo-metodychni osnovy kontroliu rozrobky ta zastosuvannia zasobiv dezinfektsii]. Kharkiv: Miskdruk. ISBN 9786176192374. [in Ukrainian].

Samiullah, Chousalkar, K. K., Roberts, J. R., Sexton, M., May, D. and Kiermeier, A. (2013) 'Effects of egg shell quality and washing on Salmonella Infantis penetration', International Journal of Food Microbiology, 165(2), pp. 77-83. doi: 10.1016/j.ijf oodmicro.2013.05.002.

Sander, J. E. and Wilson, J. L. (1999) 'Effect of hydrogen peroxide disinfection during incubation of chicken eggs on microbial levels and productivity', Avian Diseases, 43(2), pp. 227-233. doi: 10.2307/1592612.

Stegniy, B. T., Paliy, A. P., Pavlichenko, O. V., Muzyka, D. V., Tkachenko, S. V. and Usova, L. P. (2019) 'Virucidal properties of innovative disinfectant to Avian influenza virus and Newcastle disease virus', Journal for Veterinary Medicine, Biotechnology and Biosafety, 5(3), pp. 27-33. doi: 10.36016/JVMBBS-2019-5-3-6.

Svobodová, J. and Tưmová, E. (2015) 'Factors affecting microbial contamination of market eggs: A review', Scientia Agriculturae Bohemica, 45(4), pp. 226-237. doi: 10.1515/sab2015-0003.

Van de Ven, L. J. F., Baller, L., Van Wagenberg, A. V., Kemp, B. and Van den Brand, H. (2011) 'Effects of egg position during late incubation on hatching parameters and chick quality', Poultry Science, 90(10), pp. 2342-2347. doi: 10.3382/ps.2011-01467.

Wang, J. M., Firestone, M. K. and Beissinger, S. R. (2011) 'Microbial and environmental effects on avian egg viability: Do tropical mechanisms act in a temperate environment?', Ecology, 92(5), pp. 1137-1145. doi: 10.1890/10-0986.1.

Zavgorodniy, A. I., Stegniy, B. T., Paliy, A. P., Gorzheiev, V. M. and Smirnov, A. M. (2013) Scientific and Practical Aspects of Disinfection in Veterinary Medicine [Naukovi ta praktychni aspekty dezinfektsii u veterynarii]. Kharkiv: FOP Brovin O. V. ISBN 9789662445596. [in Ukrainian]. 